January 1, 2003

\title{
Taxes and Location of Foreign Direct Investments: an Empirical Analysys for the European Union Countries
}

Roberta De Santis

Maria Cristina Mercuri

Claudio Vicarelli 


\section{Taxes and location of foreign direct investments: An empirical analysis for the European Union countries.}

By Roberta De Santis, Cristina Mercuri e Claudio Vicarelli

\section{Introduction}

Productive internationalisation is one of the central aspects of the globalisation of world economy. The main tool it uses is investments flows made by operators in countries other than those where their activities are located (Foreign Direct Investments or FDI) ${ }^{1}$.

The fiscal treatment is one of the main factor determining country's competitiveness and seems to be also one of the major determinants of FDI flows in industrialised countries.

This paper aims at verifying the impact of fiscal variables in the multinational firms' localisation choices within the European Union Member States. In particular, the sensitivity of bilateral foreign direct investments towards EU member countries to the receiving country's fiscal characteristics is tested.

The paper is organised as follows. Section 1 presents an analysis of FDI and main fiscal variables trends in European Union countries for the period 1990-1998 with particular attention on the relationship between "taxation" and FDI inflows. Section 2 presents a brief survey of theoretical and empirical literature on FDI inflows determinants among industrialised countries with a particular focus on fiscal determinants; the model specification and the description of the variables are presented in section 3, results of empirical analysis follows in Section 4. Concluding remarks are offered in Section 5.

\section{FDI and taxes: trends in European Union}

In terms of size, the EU represents the major area for FDI in- and outflows (in 1999, the FDI flows exceeded 300 and 500 billion dollars respectively).

Within the Union area, whenever very heterogeneous tax schemes coexist, Member States show different performances in terms of FDI inflows (Table 1).

Between 1998 and 19992, the inflows to the United Kingdom (which is the main host country in the European Union) have grown, as were those to Sweden and Ireland. Italy confirmed its lack

\footnotetext{
${ }^{1}$ On the basis of the OECD, Eurostat and IMF definition Foreign Direct Investments (FDI) are international investments aimed at the acquisition of durable participations (control, on an equal basis or on a minority basis) in a foreign firm
} 
of attraction capacity compared to the other main European economies, while Germany - which in the previous years had received only modest percentages of FDI - registered a positive trend.

Table 1

FDI and fiscal variables: recent trends

\begin{tabular}{|l|c|c|c|c|c|c|c|c|}
\hline & \multicolumn{2}{|c|}{$\begin{array}{c}\text { FDI inflows } \\
(\% \text { EU total) }\end{array}$} & \multicolumn{2}{c|}{$\begin{array}{c}\text { Tax burden } \\
\text { (\% GDP })\end{array}$} & \multicolumn{2}{c|}{ Tax wedge } & \multicolumn{2}{c|}{$\begin{array}{c}\text { Corporate tax } \\
\text { rate }\end{array}$} \\
\hline & $\mathbf{1 9 9 8}$ & $\mathbf{1 9 9 9}$ & $\mathbf{1 9 9 8}$ & $\mathbf{1 9 9 9}$ & $\mathbf{1 9 9 8}$ & $\mathbf{1 9 9 9}$ & $\mathbf{1 9 9 8}$ & $\mathbf{1 9 9 9}$ \\
\hline Austria & 1.8 & 0.9 & 46.0 & 45.8 & 54.7 & 54.5 & 34.0 & 34.0 \\
\hline Belgium and Luxemb. & 9.1 & 5.2 & 44.9 & $47.4(1)$ & 52.7 & 52.5 & 38.8 & 38.8 \\
\hline Denmark & 2.7 & 2.4 & 50.4 & 51.6 & 60.1 & 61.1 & 34.0 & 32.0 \\
\hline Finland & 4.9 & 1.0 & 46.3 & 46.3 & 57.4 & 57.2 & 28.0 & 28.0 \\
\hline France & 11.9 & 12.8 & 46.1 & 46.9 & 55.9 & 56.8 & 36.7 & 36.7 \\
\hline Germany & 8.5 & 8.8 & 42.4 & 43.2 & 53.3 & 54 & 54.3 & 51.6 \\
\hline Greece & 0.3 & 0.3 & 37.5 & 37.8 & 42.4 & 43.5 & 40.0 & 40.0 \\
\hline Ireland & 3.4 & 6.0 & 33.2 & 34.4 & 41.6 & 43 & $10.0(3)$ & $10.0(3)$ \\
\hline Italy & 1.2 & 1.6 & 43.0 & 43.3 & 50.3 & 50.3 & 41.2 & 41.2 \\
\hline Netherlands & 16.8 & 11.1 & 40.6 & 41.8 & 47.8 & 49.2 & 35.0 & 35.0 \\
\hline Portugal & 1.1 & 0.2 & 35.8 & 38.5 & 41.4 & 44.1 & 37.6 & 37.6 \\
\hline Spain & 4.8 & 3.1 & 34.9 & 35.6 & 41.5 & 42.3 & 35.0 & 35.0 \\
\hline Sweden & 7.9 & 19.7 & 54.4 & 54.6 & 64.3 & 64.9 & 28.0 & 28.0 \\
\hline United Kingdom & 25.6 & 26.9 & 37.9 & 38 & 39 & 38.7 & 31.0 & 30.0 \\
\hline European Union(2) & 100 & 100 & 42 & 42.9 & 50.1 & 50.5 & 34.5 & 34.1 \\
\hline
\end{tabular}

Source: Unctad (2000), Bank of Italy (2000), Martinez Mongay (2000), Baker and MacKenzie (1999)

(1)Figure refers to Belgium

(2) EU average

(3) See note 25

As shown by Table 1, the analysis of the latest data does not enable to draw univocal indications on the impact of main fiscal variables in the multinational firms' localisation decisions.

The long-term trends of the variables under examination seem to point to the existence of a negative relationship between "taxation" and FDI inflows. As shown by data, in the period under examination (1990-1998) ${ }^{3}$ the FDI localisation decisions in the EU countries were strongly

(M\&A) or at creating a foreign branch (Greenfield investments) implying a certain degree of involvement of the investor in the direction and management of the created or acquired firm.

${ }^{2}$ The year 1999 is the last year for which data on FDI are available; however these are not unbundled by country of origin but are aggregated (see UNCTAD, 2000). The unbundled data by country of origin are indeed available up to 1997 for most countries.

${ }^{3}$ The period 1990-98 was chosen for homogeneity with that used for the econometric analysis (see note 20). 
influenced by fiscal variables. In that lapse of time, low-taxation countries experienced larger FDI inflows as a percentage to GDP than those observed in medium- and high-taxation countries ${ }^{4}$.

\section{Chart 11}

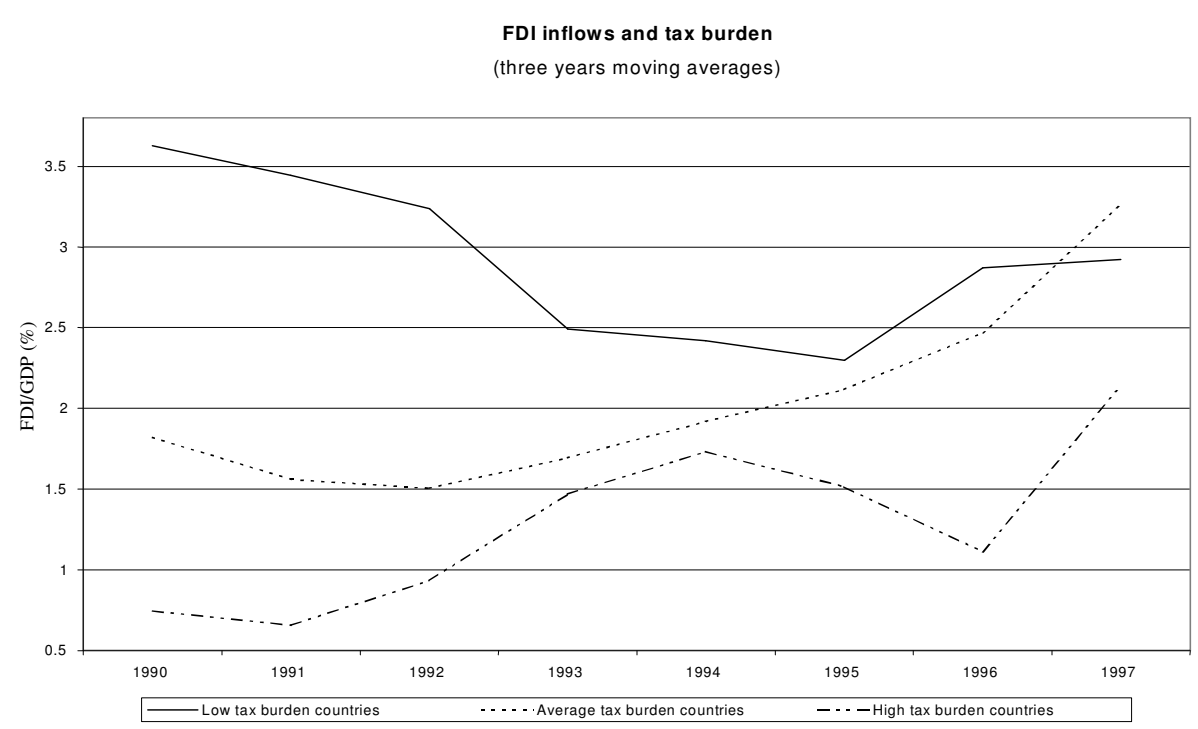

${ }^{1}$ The chart reports for each year the averages of FDI inflows divided by GDP (\%). Low tax burden countries are: Greece, Ireland, Portugal, United Kingdom and Spain; medium tax burden countries are: Austria, Belgium, France, Germany, Italy, Netherlands e Finland; high tax burden countries are Denmark and Sweden.

Source: calculation on OECD (various years), World Bank (various years) and Bank of Italy (2000).

This phenomenon may be analysed by making reference to two major fiscal indicators, namely tax burden (Chart 1) - representing the "wider" indicator for the taxation role for a country's economy - which mirrors the whole tax burden borne by households and firms, and the tax wedge on labour (Chart 2), indicating the differential between wages and salaries received by workers net of taxes and of what the firm pays in terms of labour cost ${ }^{5}$. This difference derives from the fact that labour income is taxed three times: the first time through indirect labour costs aimed at social security contribution; the second time through the residual income taxation and the third time through indirect taxation when the residual income is consumed.

Tax burden and tax wedge are built on the basis of macroeconomic variables as they are registered by National Accounts in the single EU Member States. The FDI/taxation relation may

\footnotetext{
${ }^{4}$ It is worth noticing that the presence of Ireland, which is characterised by a "preferential tax rate" on entrepreneurial income, strongly influences the average of the FDI inflows to low-taxation countries (see note 24). The exclusion of Ireland from the group determines a considerable reduction in the average value of FDI inflows.

${ }^{5}$ That approach follows Layard et al. (1991) as resumed by Martinez-Mongay (2000).
} 
also be outlined by using the corporate tax rate as reference (Chart 3$)^{6}$, which represents a more immediate, albeit incomplete ${ }^{7}$, indicator of the tax burden weighting on FDI.

Chart $2^{1}$

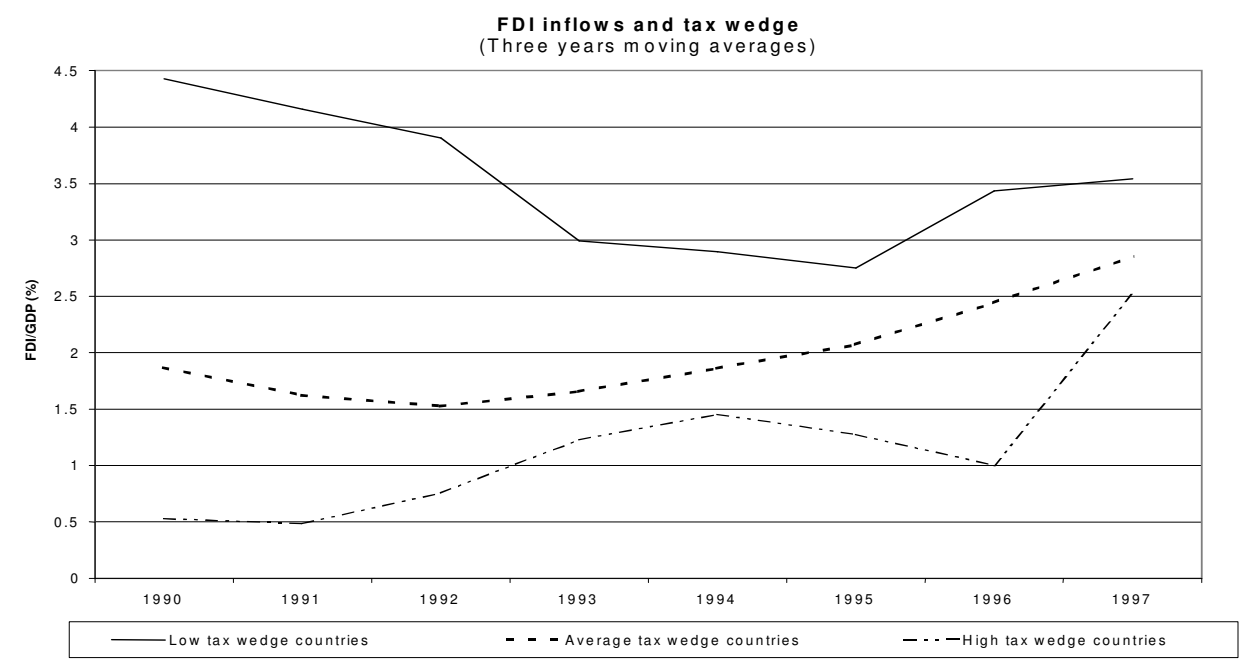

${ }^{1}$ Figure reports for each year the averages of FDI inflows divided by GDP (\%). Low tax wedge countries are: Ireland, Portugal, United Kingdom and Spain; medium tax wedge countries are: Austria, Belgium, France, Germany, Greece, Italy and Netherlands; high tax wedge countries are Denmark, Finland and Sweden.

Source: calculation on OECD data (various years), World Bank (various years) and Martinez-Mongay (2000).

A relevant aspect, left unfocused by this fiscal variable, concerns the specific FDI incentives introduced in single Member Countries. In chart 3, the anomalous positions of Netherlands and Belgium - two Member States experiencing high FDI inflows in spite of the high corporate tax rate - indicates the presence of specific fiscal incentives for foreign investors. Indeed, the analysis of the two countries' fiscal provisions confirms this assumption ${ }^{8}$.

Furthermore, it is worth noticing that a major element to determine the FDI fiscal treatment is the presence of bilateral tax Treaties ${ }^{9}$ : indeed, through taxation or exemption, these enable the reimbursement (or the payment partial or total exemption) of a wide tax percentage, thus reducing double taxation of incomes obtained in countries other than that of origin.

\footnotetext{
${ }^{6}$ Chart 3 does not include Greece, as there are no data on the corporate tax rates on company taxation homogeneous with those of the other countries.

7 The corporate tax rate analysis alone does not take into account many aspects concerning the taxable income computation: interest detaxation, capital allowance, inventory computation methods, loss apportionment, industrial group taxation.

${ }^{8}$ For a thorough examination of fiscal incentives to FDI in the European Union, see Schlitzer and Zaghini (2000).
} 
The presence in the European Union of countries which adopted different taxation systems for foreign incomes (tax credit $\mathrm{v}$. tax exempt countries) might represent a fundamental element in the analysis of international investment decision: the investors of countries with a tax credit regime are indeed less sensitive to the tax rate differential compared to those residing in States which foresee exemption schemes ${ }^{10}$.

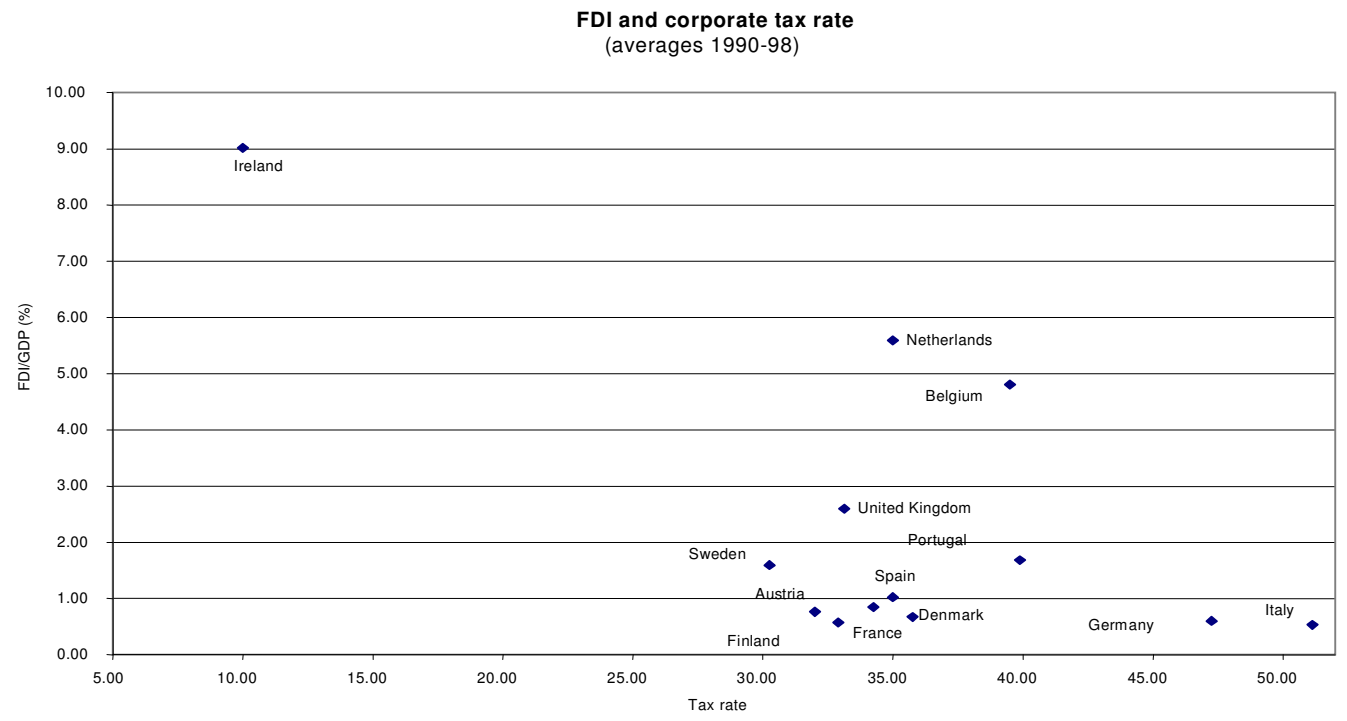

Chart 3

Source: calculation (various years), World Bank (various years) and Gropp and Kostial (2000).

To limit this heterogeneous treatment which might bring about distortions, the European Union envisages a regulation to simplify and uniform the system of taxation applicable to parent companies and their subsidiaries in different Member States (previously regulated by bilateral treaties), particularly for what concerns the distribution of profits (Directive of the European Council 90/435/EEC) $)^{11}$.

\section{A brief survey of litterature}

\footnotetext{
${ }^{9}$ To quote an example, the United Kingdom, which over the past few years was one of the main investors and one of the main FDI receiving countries among the developed countries, subscribed with 11 Member States (including Italy) bilateral agreements allowing for considerable tax reimbursements.

${ }^{10}$ Firms residing in Member States where there is a tax credit scheme are subject to the internal tax rate, even though they are entitled to the deduction of the paid tax in the country where the investment is located.

${ }^{11}$ The Directive states that profits distributed to non-residents are not subject to taxation if the share ownership of a foreign company exceeds $25 \%$. Besides, only $5 \%$ of the gross profits must be computed as taxable income in the company's country of legal residence.
} 
It is worth stressing that this paper focuses on FDI inflows determinants, with a particular stress on fiscal variables, in a panel of European Union countries. Thus, we are mainly concerned with theories explaining FDI among industrialised countries ${ }^{12}$.

The conceptual framework of the paper draws on the standard OLI approach ${ }^{13}$.(Ownership, Location, Internalisation advantages) used in analysing multinational enterprises. Ownership advantages pertain to products or production processes which other firms do not have access to, such as patents, or intangible elements, such as reputation for quality or brand names. Location advantages pertain to the host country's quality of business environment, such as low factor prices or customer access, together with relatively low trade barriers or transport costs making FDI more profitable than exporting. Finally, internalisation advantages derive from the firm's interest in maintaining its knowledge assets internal ${ }^{14}$.

Starting from the OLI theoretical framework, the "new FDI theory" mainly refers to the ownership and location advantage, including MNC's in general equilibrium models. It should be stressed that, while the OLI framework is rather a normative theory, derived from the observation of the MNC's behaviour in the localisation decision planning, the "new FDI theory" seems to be heuristically more adequate to an analysis in a theoretical model framework.

In early literature (Helpman E. (1984), Helpman E. and Krugman P. (1985)) the presence of MNCs in a foreign country was explained in terms of differences in relative factor endowments among countries. Transport costs being null, the location of MNCs abroad is determined by the differences in endowments. The main shortcoming of this approach is that it seems suitable to explain "vertical" FDI (when firms locate different stages of production in different countries by taking advantage of differences in factor costs), but it cannot explain "horizontal" FDI (when firms locate similar types of production activities). The latter phenomenon has been observed among

\footnotetext{
${ }^{12}$ For a classification of FDI determinants by host country, see UNCTAD (1998), Chapter IV. A review of econometric studies on determinants is also contained in UN (1992). A survey of recent research on theory of multinational enterprise is in Markusen (1995).

${ }^{13}$ It is widely agreed that multinational companies (MNCs) engage in FDI when three sets of determining factors simultaneously emerge: notably the presence of: i) ownership-specific competitive advantages, ii) location advantages in the host countries and iii) better trade benefits in intra-firm as against arm's-length relationship between investor and recipient (internalisation advantage). This theoretical approach, introduced by Dunning (1977, 1981), is known as the OLI framework

14 This may happen for several reasons. For instance, markets for assets or production inputs (technology, knowledge, management) may involve significant transaction costs or time-lags. Or else, a firm might be interested in retaining its exclusive right on assets (i.e. knowledge) which permits to hold significant competitive advantages (i.e. monopoly rents).
} 
industrialised countries during the past few years. Thus, it seems that this approach cannot fully explain recent FDI trends ${ }^{15}$.

This conclusion leads us to a more recent literature, whose starting point (Brainard S.L. 1993) is that multinational activities are driven by trade-offs between "proximity" and "concentration" advantages, rather than by differences in factor endowments.

The proximity advantage stems from firm-level economies of scale, whereby any type of "knowledge capital" (like R\&D activity) is transferable to the affiliates and allows MNCs to be closer to the foreign market. The concentration advantage derives from traditional plant-level economies of scale, which make it more profitable to concentrate production in one location and supply foreign markets by exports. Whenever the proximity advantage outweighs the concentration advantage, FDI flows arise. It is more likely to happen the higher are intangible assets relative to the fixed costs of opening up an affiliate, and the higher are transport costs.

In the framework of the mentioned theoretical literature our focus on capital mobility driven by fiscal condition is motivated by a relative scarcity of empirical studies on this issue for EU.

Past empirical work on relationship between FDI and corporate tax rate and fiscal condition in general has focused mainly on US as Bond et al. (1999). The studies which were undertaken before 1990 found mixed evidence, concluding in the majority of the cases that FDI flows are not very sensitive to tax differentials (Hines 1996, Hartman 1984, Boskin e Gale 1987, Young 1988).

The recent empirical literature concerning EU is on the contrary generally unambiguous in finding that multinational use the new opportunity of globalisation for minimising tax burden through the relocation of mobile capital among countries with more friendly fiscal conditions.

Hines (1996), compares the inter-state distribution of investments from foreign countries according to their fiscal schemes (credit v. exemption). He shows that firm originating from countries offering credit schemes are less likely to invest in countries imposing low taxation.

Business surveys carried out by Devereux and Pearson (1989) for the Ruding Committee support the view that tax system play a considerable role in the firm' investment decisions. However a recent survey of multinational conducted by Deloitte Touche (1996) found that although taxes are influential in investment decision making, a large numbers of investors are unfamiliar with many of the available beneficial tax incentives, including those in countries where they have already invested.

Devereux e Freeman (1995) carried out a study on the impact of taxation on FDI flows among seven countries for the period 1984-89, they find that the tax burden, though not being determinant

\footnotetext{
${ }^{15}$ Markusen and Maskus (1999b), give strong empirical support to the predominance of horizontal model.
} 
in the choices between investing abroad or in the country of origin, is indeed significant in explaining the localisation choices of FDI. Devereux and Griffith (1998) use individual firm activity data of US multinationals investing in Europe (restricted to the UK, France and Germany). In line with Markusen and Brainard, they show that the choice between producing abroad or exporting is determined by proximity-concentration trade-off; then, the choice of the location, conditional to the decision to produce abroad rather than to export, is driven by taxation and other cost-related factors

The most recent literature on taxes impact on FDI flows in EU using bilateral flows Bénnassy-Quéré et al. (2000), Gropp e Kostial (2000), Schlitzer and Zaghini (2000) and Gorter Parikh (2000) confirms the sensitivity of location decision of MNCs to fiscal conditions of host countries for the whole of the Member State of European Union.

\section{Model specification and description of variables}

An econometric exercise was carried out through a panel data estimate to test the impact of taxation in determining the FDI inflows trends and geographical localisation.

The starting point in the specification process of the equation was the gravitational model, whereby the explicative variables of FDI inflows are dimension of receiving and investing countries, distance and trade barriers. This approach - which was developed in the sixties to explain bilateral trade flows ${ }^{16}$ - proved to be suitable in explaining the main developments of trade relations over the past few years and, in particular, the tendency of developed countries to have tighter trade relations with countries with similar economic characteristics (intra-industrial trade) ${ }^{17}$.

The gravitational model considers mainly macroeconomic and geographical explicative variables. In this work, though maintaining the bilateral structure typical of this approach, the specification was augmented by including - alongside with traditional variables - "environmental" variables (proxies for infrastructures, degree of technical innovation and State presence in the economy) and fiscal variables (tax burden, total tax wedge on labour, corporate tax rate). According

\footnotetext{
${ }^{16}$ The gravitational estimate takes its theoretical bases from physics. According to the gravitational theory, the attraction between bodies is directly proportional to the mass product and inversely proportional to the squared distance. The bilateral trade flows in this kind of models are positively influenced by the overall market dimensions of the origin and destination countries, by the destination market size and by its growth potentiality. Indeed, the geographical distance meant as proxy of transport costs has a negative impact on trade flows. See Linnemann (1966).

${ }^{17}$ For an estimate of FDI bilateral flows with the gravitational equation, see Di Mauro (1999), Brenton and Di Mauro 1999), Brenton et al. (1999), Eaton and Tamura (1996).
} 
to the most widespread theory ${ }^{18}$, the relative advantage for a firm to invest abroad rather than in the home country and the choice among potential destination countries depend not only on the macroeconomic and geographical conditions, but also on structural and fiscal ones.

In the adopted specification, the dependent variable is represented by bilateral FDI inflows in dollars normalised with the receiving country's GDP in dollars. Thirteen FDI-receiving countries are considered (the EU countries, data for Belgium and Luxembourg aggregated ${ }^{19}$, with the exclusion of Greece as there are no homogeneous data) and fourteen investing countries (the EU countries with the exclusion of Greece and Ireland, data on Belgium and Luxembourg aggregated, and including the United States and Japan).The estimate refers to the period 1990-98 ${ }^{20}$

Three types of explicative variables were introduced:

i) macroeconomic variables, such as the receiving country market size, the development degree of the investing country compared to the receiving country and the degree of bilateral openness;

ii) "environmental" variables, such as the degree of technical innovation of the receiving country, its expenditure for infrastructure, an indicator of the State presence in the economy;

iii) fiscal variables such as the tax burden, the total tax wedge on labour, the implicit corporate tax rate and the corporate tax rate.

Furthermore, it is necessary to underline that diagnostic tests on the proposed specification (Hausman test ${ }^{21}$ ) indicate that using a panel data with fixed-effect methodology is appropriate: it includes specific regression constants for the observations on different market-investor couples (market and investor countries) $^{22}$.

The introduction of those constants embodied the impact of specific characteristics, that are not controlled for by the variables included in the specification tested, linked to the couples of countries involved in the investment (market country and investor).

${ }^{18}$ See Dunning (1977), Dunning (1981).

${ }^{19}$ The OECD uses data on FDI for Belgium and Luxembourg aggregated due to survey methodology.

${ }^{20}$ The year 1990 is chosen as estimated period start, as it is the beginning of the first stage of EMU. In 1990 most of the restrictions at capital movements were abolished. Thus it would seem that this year is a particularly significant for the strong signal of evolution of the European integration process given to international investors. Conversely, 1998 is the most recent year for which homogeneous and thorough data on bilateral FDI inflows to the Member States are available.

${ }^{21}$ The Hausman test is based on Wald's criterium. Under the null hypothesis, both the generalised least squares estimator of the random-effect model and the ordinary least squares estimator with the inclusion of specific constants for the market-country couples are consistent, but the latter is an inefficient estimator. In case of rejection of the null hypothesis, the generalised minimum square estimator of the random-effect model provides inconsistent estimates and the fixed-effect model must be adopted.

${ }^{22}$ Apparently, the bilateral constants seem to include the distance effect as well (a variable which is generally included in gravitational equations) which, in the adopted specifications, is always statistically non significant. 
The proposed equation is as follows:

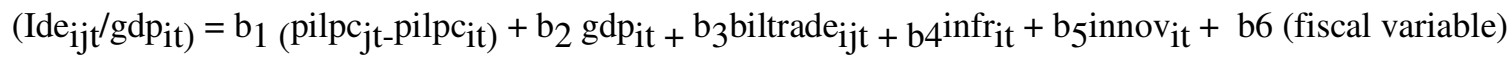

where $\mathrm{i}$ is the market (receiving country), $\mathrm{j}$ is the investor country and $\mathrm{t}$ is the year.

In particular, bilateral FDI inflows are expected to be positively influenced:

i) by the differential between the per capita GDP in dollars of the investor and receiving countries, as a proxy of the differential between the development level (pilpcjt-pilpc ${ }_{i t}$ );

ii) by the gdp of the receiving country, considered as proxy of the market demand ( $\mathrm{gdp}_{\mathrm{it}}$ );

iii) by the degree of bilateral openness, computed as the sum of bilateral export-import flows between investor and receiving countries as a percentage of the receiving country's GDP (biltrade $_{\mathrm{ijt}}$ );

iv) by the transport infrastructures proxied by the ratio between the road-railway length and the receiving country's total area $\left(\right.$ infr $\left._{i t}\right)$;

v) by the number of patents required by the receiving country's resident population per 10,000 inhabitants (innovit).

Bilateral FDI flows are indeed expected to be negatively correlated:

vi) to the following fiscal variables (separately or jointly) included in alternative estimates both referred to the receiving country or as differentials between receiving and investing countries:

- tax burden (personal income taxation, indirect taxation, capital account and social contributions)/GDP), $\left(\text { prefi }_{i t}\right)^{23}$;

- tax wedge on labour, given as the sum of social contributions, income taxes and consumption duties (wedgit),

- $\quad$ corporate tax rate, $\left(\right.$ alegit $\left._{i t}\right)$.

\section{Estimates results}

In the empirical analysis, a wide range of potential FDI determinants in the Member States is considered: alongside with macroeconomic variables (per capita GDP, GDP, exchange rate

\footnotetext{
${ }^{23}$ Capital account taxes are excluded for Japan and the United States.
} 
volatility $^{24}$, degree of market openness) and with environmental conditions (infrastructures, technological innovation), a group of possible fiscal determinants is also included.

With few exceptions, the estimated coefficients are statistically significant in all the estimated specifications (Tab.2). The signs are the expected ones. In particular, the fiscal indicators are negatively correlated to the FDI inflows towards the selected countries, in keeping with what verified in the latest empirical literature on this topic.

The robustness of the overall estimate was verified as against changes in the fiscal variable specification, in the estimate period and equation specification. In particular, the case of Ireland ${ }^{25}$ seems to be representative in explaining the negative correlation between corporate tax rate and FDI flows. Indeed, by excluding this country from the panel, the specification which includes the corporate tax rate as fiscal variable is less significant (the alternative specifications, tax burden and tax wedge, are equally significant). The exclusion of Belgium and Netherlands - Member States towards which the investors have particular fiscal benefits not included in the model - seems to improve the estimates' significance.

The inclusion, in the estimated equations, of a trend which proves statistically significant in the most of specifications does not mine the significance of parameters by showing, on the one hand, that the time evolution seems to play a role in determining the bilateral FDI inflows and, on the other hand, that the estimates are robust.The results of the econometric exercise show that, for the whole of the countries considered, the selected determinants significantly influence FDI inflows in the European Union countries.

With regard to macroeconomic variables, FDI inflows are positively correlated to the per capita GDP differential between investor and destination countries. This result, alongside with the more immediate direct relation existing between the degree of development of a State ${ }^{26}$ and its

24 Among macroeconomic variables, we included in the equation also the exchange rate volatility. The impact of the exchange rate volatility on FDI flows is theorically ambiguous. If a foreign firm intends to sell on the local market, an higher nominal exchange rate volatility can induce higher FDI; if the production is partially re-exported, this benefit vanishes. If the market seeking determinants are those driving the multinational firm choice of localisation, then we could expect a positive relationship between FDI flows and exchange rate volatility. It is to be stressed that the exchange rate volatility between European currencies and against the dollar has dramatically reduced during the 90's.; this determinant has reduced its impact in the period of our econometric analysis. Our results showed a positive relationship, but this variable is significant at a low level in all the specification reported, so we have dropped it.

25 In 1981, Ireland introduced a "preferential" corporate tax rate on the entrepreneurial income in the manufacturing sector (and in some area of the service sector) equalling 10\% (the lowest in the European Union), which will remain into force up to 2002. Starting from 2003, according to the ruling of the European Commission, the applied tax rate must equal $12.5 \%$. In the period under examination, most foreign investments drew benefits from this tax rate. For this reason, it is the one used in econometric analysis. It is reasonable to assume that, under these conditions, Ireland may be considered somehow an outlier.

26 The relation between the GDP of the investor country and the FDI inflows was verified and proved positive and statistically significant. That result is in keeping with what verified by Bénassy-Quère et al. (2000). 
availability of resources to invest abroad, introduces spurious elements in a North-North type of analysis model $^{27}$.

Tab.2

Estimates results

\begin{tabular}{|c|c|c|c|c|c|}
\hline \multicolumn{4}{|l|}{ Dependent variable ide/pil (1) } & \multirow[b]{2}{*}{ IV } & \multirow[b]{2}{*}{$\mathrm{V}$} \\
\hline & $\mathrm{I}$ & II & III & & \\
\hline Period of estimate & 1990-98 & $\begin{array}{l}1990-98 \\
\end{array}$ & 1990-1998 & $\begin{array}{l}1990-98 \\
\end{array}$ & 1990-98 \\
\hline Observations & 1209 & 1209 & 1209 & 1209 & 1209 \\
\hline Per capita GDP differential $(j-i)$ & $\begin{array}{c}7.13 \mathrm{E}-06 \\
(3.70)\end{array}$ & $\begin{array}{l}6.49 \mathrm{E}-06 \\
(3.33)\end{array}$ & $\begin{array}{c}7.06 \mathrm{E}-06 \\
(3.42)\end{array}$ & $\begin{array}{l}5.84 \mathrm{E}-06 \\
(2.99)\end{array}$ & $\begin{array}{l}5.92 \mathrm{E}-06 \\
(3.03)\end{array}$ \\
\hline GDP partner country & $\begin{array}{c}3.21 \mathrm{E}-08 \\
(2.22)\end{array}$ & $\begin{array}{c}2.21 \mathrm{E}-08 \\
(1.57)\end{array}$ & $\begin{array}{l}2.48 \mathrm{E}-08 \\
(1.71)\end{array}$ & $\begin{array}{l}1.50 \mathrm{E}-06 \\
(1.15)\end{array}$ & $\begin{array}{l}1.47 \mathrm{E}-08 \\
(1.10)\end{array}$ \\
\hline Bilateral degree of openness & $\begin{array}{l}0.049 \\
(7.11)\end{array}$ & $\begin{array}{l}0.048 \\
(6.98)\end{array}$ & $\begin{array}{l}0.044 \\
(6.65)\end{array}$ & $\begin{array}{l}0.048 \\
(6.80)\end{array}$ & $\begin{array}{l}0.049 \\
(7.03)\end{array}$ \\
\hline Inventiveness coefficient & $\begin{array}{l}0.023 \\
(2.92)\end{array}$ & $\begin{array}{l}0.025 \\
(3.02)\end{array}$ & $\begin{array}{l}0.017 \\
(2.23)\end{array}$ & $\begin{array}{l}0.023 \\
(2.69)\end{array}$ & $\begin{array}{l}0.025 \\
(2.81)\end{array}$ \\
\hline $\begin{array}{l}\text { Transport infrastructure partner } \\
\text { country }\end{array}$ & $\begin{array}{l}0.042 \\
(2.83)\end{array}$ & $\begin{array}{l}0.039 \\
(2.61)\end{array}$ & $\begin{array}{l}0.044 \\
(2.96)\end{array}$ & $\begin{array}{l}0.038 \\
(2.48)\end{array}$ & $\begin{array}{l}0.039 \\
(2.56)\end{array}$ \\
\hline Total fiscal wedge on labour & $\begin{array}{l}-0.003 \\
(2.27) \\
\end{array}$ & & & & \\
\hline $\begin{array}{l}\text { Fiscal wedge on labour } \\
\text { differential partner v. reporting } \\
\text { country }\end{array}$ & & $\begin{array}{l}-0.002 \\
(2.31)\end{array}$ & & & $\begin{array}{l}-0.002 \\
(2.19)\end{array}$ \\
\hline $\begin{array}{l}\text { Total fiscal pressure differential } \\
\text { partner v. reporting country }\end{array}$ & & & $\begin{array}{l}-0.001 \\
(1.68)\end{array}$ & & \\
\hline $\begin{array}{l}\text { Corporate legal tax rate } \\
\text { differential partner v. reporting } \\
\text { country }\end{array}$ & & & & $\begin{array}{l}-0.001 \\
(1.71)\end{array}$ & $\begin{array}{l}-0.001 \\
(1.82)\end{array}$ \\
\hline $\mathrm{R} 2$ & 0.46 & 0.46 & 0.48 & 0.45 & 0.46 \\
\hline R2adj & 0.39 & 0.39 & 0.40 & 0.38 & 0.38 \\
\hline D-W & 1.9 & 1.9 & 1.9 & 1.9 & 1.9 \\
\hline Hausman test (2) & $\begin{array}{c}\chi_{2} 1.56 \\
(0.46)\end{array}$ & $\begin{array}{c}\chi_{2} 1.25 \\
(0.53)\end{array}$ & $\begin{array}{c}\chi_{2} 0.73 \\
(0.69)\end{array}$ & $\begin{array}{l}\chi_{2} 1.87 \\
(0.39)\end{array}$ & $\begin{array}{l}\chi_{2} 1.77 \\
(0.41)\end{array}$ \\
\hline
\end{tabular}

(1) $t$ of Student is reported in parenthesis.

(2) $p$ value in parenthesis

This last, by confirming the hypothesis that intra-sectorial trade relations and horizontal FDI ${ }^{28}$ prevail among industrialised countries, would implicitly indicate the non relevance of different

\footnotetext{
${ }^{27}$ The North-North model is a scheme for the analysis of trade and productive relations among industrialised countries. See, among others, Brainard (1993) and Markusen et al. (1996).

${ }^{28}$ A horizontal FDI is a foreign investment aimed at de-localising productive activities similar to those of the parent company. A vertical FDI implies the delocalisation of activities which are upstream or downstream the productive activity of the parent company.
} 
degrees of development of the States, which are however supposed to be very limited. Conversely, the empirical evidence shows that these differences within the European Union are relevant. This might partially be due to the fact that the per capita GDP differential is indirectly influenced by the effects of wage gaps ${ }^{29}$ on FDI flows, thus indicating that a higher level of relative development thus larger labour incomes - in the destination country might somehow discourage investors.

Furthermore, the flows of bilateral FDI are positively correlated to the degree of bilateral opening between countries ${ }^{30}$. This result seems to indicate that elements of complementarity between FDI flows and trade flows among countries prevail ${ }^{31}$, thus suggesting that within the European Union the aims of multi-national investors are also linked to the strengthening of distribution activities abroad and to the possibility to serve the local market. To confirm the relevance of market seeking determinants, the positive relation between FDI and host country GDP seems significant as the latter is a proxy of the market demand.

Tab. 3

FDI inflows estimated elasticity to main explanatory variables

\begin{tabular}{|l|c|c|c|}
\hline & I & II & III \\
\hline $\begin{array}{l}\text { Per capita GDP differential investing and partner } \\
\text { country }\end{array}$ & 0.04 & 0.04 & 0.03 \\
\hline GDP in the partner country & 0.08 & 0.07 & 0.05 \\
\hline Bilateral degree of openness & 0.80 & 0.88 & 0.87 \\
\hline Transport infrastructures in the partner country & 1.79 & 1.58 & 1.52 \\
\hline Inventiveness coefficient in the partner country & 0.19 & 0.26 & 0.26 \\
\hline $\begin{array}{l}\text { Tax burden differential, partner v. reporting } \\
\text { country }\end{array}$ & $\mathbf{- 0 . 0 1}$ & & \\
\hline $\begin{array}{l}\text { Tax wedge on labour differential, partner v. } \\
\text { reporting country }\end{array}$ & & $\mathbf{- 0 . 0 2}$ & $\mathbf{- 0 . 0 1}$ \\
\hline $\begin{array}{l}\text { Corporate tax rate differential, partner v. } \\
\text { reporting country }\end{array}$ & & & \\
\hline
\end{tabular}

Besides, the results of the econometric exercise confirm the importance of "environmental" variables, with a particular relevance of transport infrastructures, in explaining the

\footnotetext{
${ }^{29}$ This variable (explicitly included in the estimate) proves non significant in the specification adopted.

${ }^{30}$ Similar results were reached by Bénassy-Quère et al. (2000) and by Gropp and Kostial (2000).

${ }^{31}$ For a thorough analysis of the FDI/trade relation, see Mori and Rolli (1998).
} 
internationalisation process among industrialised countries as it emerges from the theory and from empirical evidences ${ }^{32}$.

With regard to the influence of taxation, all the regressors used in the estimates present the expected sign, always showing a negative and significant relation with the FDI flows. Those variables are more significant if expressed in terms of differential between receiving and investor countries: a tax rate increase in the destination country as against the investor country reduces FDI inflows ${ }^{33}$.

The analysis of the elasticities ${ }^{34}$ of FDI inflows to the explicative variables gives more detailed indications, which apparently confirm the importance of taxation in the decisions on business localisation (Table 3).

Tab. 4*

\begin{tabular}{|c|c|c|c|c|}
\hline Ranking & $\begin{array}{c}\text { Total fiscal wedge on } \\
\text { labour } \\
\text { (1990-98 average) } \\
\end{array}$ & Ranking & Elasticities & $\begin{array}{l}\mathrm{B}=\text { below the average wedge } \\
\mathrm{A}=\text { above the average wedge }\end{array}$ \\
\hline United Kingdom & $37.9 \%$ & Ireland & 0.04 & B \\
\hline Portugal & $39.3 \%$ & United Kingdom & 0.08 & $\mathbf{B}$ \\
\hline Spain & $40.7 \%$ & Portugal & 0.08 & B \\
\hline Ireland & $41.6 \%$ & Netherlands & 0.08 & B \\
\hline Italy & $49.3 \%$ & Spain & 0.12 & B \\
\hline Netherlands & $49.6 \%$ & Belgium and Lux. & 0.15 & $\mathbf{A}$ \\
\hline Germany & $51.4 \%$ & Denmark & 0.21 & $\mathbf{A}$ \\
\hline Austria & $52.9 \%$ & France & 0.72 & $\mathbf{A}$ \\
\hline Belgium and Lux. & $54.7 \%$ & Austria & 0.91 & $\mathbf{A}$ \\
\hline France & 54.7 & Sweden & 0.93 & $\mathbf{A}$ \\
\hline Finland & 58.4 & Germany & 1.04 & $\mathbf{A}$ \\
\hline Denmark & 59.5 & Finland & 1.23 & $\overline{\mathbf{A}}$ \\
\hline Sweden & 62.0 & Italy & 1.26 & $\mathbf{B}$ \\
\hline EU average & $50.1 \%$ & & & \\
\hline
\end{tabular}

*Greece is not included due to the lack of homogeneous data

The estimated values indicate, for example, that a $1 \%$ reduction of tax wedge on labour differential between host and investor countries would increase on average FDI inflows in

\footnotetext{
${ }^{32}$ See, for example, Dunning (1977).

${ }^{33}$ These results are in keeping with the latest empirical literature, see par.2.

${ }^{34}$ Elasticity is the percentage variation of FDI inflows as a ratio of GDP due to a unitary percentage variation of the explicative variables included in the estimates. The elasticity is given by the estimated coefficient times the average regressor value for the period under examination divided by the average value of the dependent variable.
} 
percentage of GDP in a country by $0.02 \%$, while an equal reduction of the tax burden or of the corporate tax rate differentials would raise them by about $0.01 \%$.

A further exercise is then carried out to draw more detailed indications on the relevance of fiscal determinants in the single Member States. The elasticities of each EU country to total fiscal wedge on labour are calculated, with reference to FDI flows coming from the United States.

Two series of considerations emerge from the exercise. Firstly, the above-listed general results advocating the importance of fiscal variables are confirmed for all the countries. Secondly, the FDI elasticity to taxation (in the exercises total fiscal wedge on labour) seems to be higher, the larger is the fiscal wedge in the receiving country. In table 4 are reported the ranking of average values of fiscal wedge on labour for EU countries and the ranking of corresponding elasticities with respect to FDI flows coming from US. It emerges that, with the only exception of Italy, countries with fiscal wedge below the EU average (B) have lower elasticities than countries with fiscal wedge above the EU average (A).

Thus, it would seem that the FDI elasticity to taxation has no linear trend, but follows a decreasing trend as taxation diminishes ${ }^{35}$. This implies that - all other conditions remaining equal - a tax burden reduction on the part of high-taxation countries would determine a greater advantage in terms of FDI inflows than that which would emerge in a country with medium or low taxation.

\section{Concluding remarks (to be completed)}

The results of empirical analysis confirm, besides the macroeconomic variables, the importance of "enviromental" and fiscal ones to explain the FDI inward flows in Europan Union countries. In particular,

Bilateral degree of trade openess show an important role to attract FDI; this result seems to confirm, at aggregate level, a complementarity relationship between FDI and trade, in accordance to other recent empirical works.

The proxy for infrastructure show also an high impact among the FDI determinants; a suitable policy aiming to improve infrastructural endwments should enhance countries competitivness.

Among fiscal variables, the main tool of this paper, the empirical analysis would confirm the assumption that those conditioning FDI in the European Union countries are the overall tax wedge on labour and the tax burden. This suggests that business firms, while making their localisation

\footnotetext{
${ }^{35}$ This consideration of merely intuitive nature apparently shows that there is a particular reactivity of investors not only to tax variations but also to the tax level.
} 
choices, focus the attention on the overall tax and contribution burden more than on single corporate tax rates, which indeed provide only a partial (even though immediate) information ${ }^{36}$.

This result, alongside with the awareness of the existence of great differences in the tax systems within the European Union, suggests two series of considerations. Firstly, a reduction in the overall tax burden, all other conditions remaining unchanged, would raise FDI inflows; secondly, that each country - thanks to the composite nature of the examined indicator - might obtain that reduction through a recomposition within a tax structure perfectly in keeping with its own tradition.

A high-taxation country might draw considerable benefits in terms of FDI through a relatively modest tax rate reduction. This means that not necessarily each Member State must switch to very low tax rates (for example those of Ireland) to obtain an optimal combination between costs (associated to the tax rate reduction) and benefits (linked to the tax base enlargement, i.e. larger FDI flows).

Besides, the examination of the elasticities shows that a State with relatively less attractive environmental conditions might offset its relative disadvantage, as against other potential destination countries for FDI, through a lighter tax burden. Conversely, a country might prefer higher tax rates so as to finance more and better infrastructures, training and technological innovation so as to attract foreign investors.

In conclusion, it is worth underlining that, if on the one side the growing capital mobility within the European Union tends to increase the FDI elasticity to taxation; on the other side, tax policies are constrained by the Maastricht parameters and by the Stability and Growth Pact, whose stringent budget constraints leaves little room to tax rate reductions, unless they are accompanied by correspondent public expenditure reductions. Those cuts, according to some estimates, would contribute - together with a more advantageous tax system - to determine more FDI inflows in a country, provided they do not influence negatively the environmental variables, in particular, the infrastructures endowment.

\footnotetext{
${ }^{36}$ It is worth noticing that, owing to the lack of data, no estimate could be made with microeconomic real average tax rates and, in particular, with forward looking tax rates. These last enable, through suitable adjustments, to estimate the taxes on the future expected income deriving from the alternative investment decisions, and are unanimously held the most suitable rates to evaluate how the tax system interferes with business decisions (see Giannini, 2001).
} 
Appendix

Main determinants of FDI inflows

(averages 1990-98)

\begin{tabular}{|c|c|c|c|c|c|c|c|c|c|c|c|c|}
\hline Tab. 1 & \multicolumn{4}{|c|}{ Macroeconomic variables } & \multicolumn{4}{|c|}{ Structural variables } & \multicolumn{4}{|c|}{ Fiscal variables } \\
\hline & \begin{tabular}{|c|} 
FDI \\
inflows/GDP \\
$(\%)$
\end{tabular} & \begin{tabular}{|c|} 
Per capita \\
GDP \\
(US \$ in PPP) \\
\end{tabular} & $\begin{array}{c}\text { Population } \\
\text { (thousand } \\
\text { units) }\end{array}$ & $\begin{array}{c}\text { Openness degree } \\
(\text { exp+imp)/GDP } \\
(\%)\end{array}$ & $\begin{array}{c}\text { Inventiveness } \\
\text { coefficient }^{1}\end{array}$ & $\begin{array}{l}\text { Researchers } \\
\text { (each } 10000 \\
\text { LF)* }\end{array}$ & $\begin{array}{c}\text { Transport } \\
\text { infrastructures }\end{array}$ & $\begin{array}{l}\text { Government } \\
\text { presence }\end{array}$ & $\begin{array}{c}\text { Tax } \\
\text { burden }\end{array}$ & $\begin{array}{l}\text { Tax wedge } \\
\text { on labour }\end{array}$ & $\begin{array}{l}\text { Corporate } \\
\text { effective } \\
\text { tax rate }\end{array}$ & $\begin{array}{l}\text { Corporate tax } \\
\text { rate }\end{array}$ \\
\hline Austria & 0.87 & 21080.5 & 7970.4 & 54.8 & 2.53 & 6.7 & 8.7 & 48.2 & 45.0 & 52.9 & 48.9 & 32.2 \\
\hline Belgium Lux. & 5.44 & 25257.0 & 10505.1 & 89.2 & 1.28 & 9.0 & 31.2 & 45.4 & 47.2 & 54.2 & 48.9 & 39.6 \\
\hline Denmark & 0.66 & 21454.9 & 5211.2 & 50.0 & 2.40 & 10.3 & 16.5 & 57.5 & 50.6 & 59.5 & 60.0 & 35.6 \\
\hline Finland & 1.45 & 18148.4 & 5080.3 & 49.6 & 4.30 & 13.5 & 2.4 & 52.8 & 47.0 & 58.4 & 58.0 & 32.3 \\
\hline France & 0.91 & 19529.7 & 59293.7 & 37.1 & 2.17 & 12.3 & 7.5 & 49.4 & 45.7 & 54.7 & 35.0 & 34.6 \\
\hline Germany & 0.61 & 20786.2 & 79341.4 & 42.3 & 4.71 & 12.2 & 14.8 & 44.5 & 42.2 & 51.4 & 30.0 & 46.8 \\
\hline Greece & 0.47 & 12655.7 & 10386.7 & 32.3 & 0.38 & 3.5 & 2.2 & 42.1 & 33.5 & 38.8 & 20.8 & n.a. \\
\hline Ireland & 8.58 & 15845.2 & 3591.1 & 109.6 & 2.22 & 6.2 & 2.9 & 36.3 & 34.3 & 41.6 & 31.3 & 10 \\
\hline Italy & 0.50 & 19312.7 & 57153.3 & 35.1 & 1.29 & 6.1 & 7.6 & 49.2 & 42.4 & 49.3 & 46.6 & 50.0 \\
\hline Netherlands & 5.90 & 19821.4 & 15350.7 & 82.3 & 1.39 & 10.6 & 14.8 & 49.3 & 44.3 & 49.6 & 47.3 & 35.0 \\
\hline Portugal & 1.70 & 12990.3 & 9908.0 & 54.6 & 0.09 & 3.0 & 4.1 & 39.1 & 34.7 & 39.3 & 28.1 & 39.9 \\
\hline Spain & 1.03 & 14486.4 & 39132.2 & 34.8 & 0.56 & 5.0 & 3.8 & 39.4 & 35.4 & 40.7 & 29.9 & 35.0 \\
\hline Sweden & 2.36 & 19098.7 & 8746.2 & 55.0 & 4.29 & 13.3 & 2.9 & 61.2 & 52.3 & 62.0 & 52.6 & 30.0 \\
\hline UK & 2.82 & 18359.9 & 58401.6 & 42.6 & 3.22 & 9.5 & 8.4 & 41.0 & 37.1 & 37.9 & 62.9 & 35.1 \\
\hline
\end{tabular}

${ }^{\mathrm{T}}$ Number of patents asked for by resident each 10,000 inhabitants

${ }^{2}$ Roads and railways length in km divided by country area in $\mathrm{Km}^{2}$

${ }^{3}$ Current public expenditure (\%GDP)

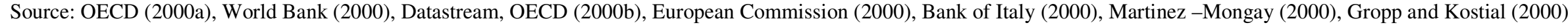



Tab. 2

\begin{tabular}{|c|c|c|}
\hline Variables & Source & Available years \\
\hline Bilateral FDI inflows & $\begin{array}{l}\text { OECD (2000), International Direct } \\
\text { Statistics Yearbook }\end{array}$ & 1980-1998) \\
\hline $\begin{array}{l}\text { Current GDP millions } \\
\text { US \$ in PPP }\end{array}$ & $\begin{array}{l}\text { World Bank Databank } \\
\text { http..sima-ext.worldbank.org }\end{array}$ & $1980-99$ \\
\hline Population (thousands) & $\begin{array}{l}\text { OECD Main Science and Technology } \\
\text { Indicators (2000). }\end{array}$ & $1980-98$ \\
\hline $\begin{array}{l}\text { Per capita GDP in } \\
\text { current US \$ and PPP }\end{array}$ & $\begin{array}{l}\text { World Bank Databank e OECD (2000), } \\
\text { Main Science and Technology } \\
\text { Indicators. }\end{array}$ & $1980-98$ \\
\hline $\begin{array}{l}\text { Bilateral trade in current } \\
\text { US \$ }\end{array}$ & Datastream e World Bank Databank & $1980-99$ \\
\hline Transport infrastructures & $\begin{array}{l}\text { European Commission (2000), EU } \\
\text { Transport in figures 2000. DG Energy } \\
\text { and Transport }\end{array}$ & $1980-98$ \\
\hline Inventiveness coefficient & $\begin{array}{l}\text { OECD (2000), Main Science and } \\
\text { Technology Indicators. }\end{array}$ & 1980-97 \\
\hline Tax burden & $\begin{array}{l}\text { Banca d'Italia (2000), Supplemento al } \\
\text { Bollettino Statistico n.68, dicembre }\end{array}$ & $1980-98$ \\
\hline Tax wedge on labour & Martinez-Mongay C., (2000) & $1960-99$ \\
\hline Tax rate on capital & Martinez-Mongay C., (2000) & 1960-99 \\
\hline Corporate tax rate & Gropp R. e Kostial K. (2000), & $1990-98$ \\
\hline
\end{tabular}




\section{References}

Auerbach A. J. and K. Hassett (1993), "Taxation and Foreign Direct Investment in the United States: A reconsideration of the Evidence", in Giovannini A., Hubbard R.G. e J. Slemrod (a cura di), Studies in International Taxation, Chicago, Chicago University Press, 119-44.

Baldwin R.E., Forslid R. and J. Haaland (1995), "Investment Creation and Investment Diversion: Simulation Analysis of the Single Market Programme", NBER Working Paper, n.5364.

Boskin M., Gale W., (1987), "New Results on the Effect of Tax Policy on the International Location of Investment", in The Effets of Taxation on Capital Accumulation, ed. by M. Feldsten, University of Chicago Press, Chicago.

Brainard S.L. (1993), "A Simply Theory of Multinational Corporation and Trade with a Trade-off between Proximity and Concentration", NBER Working Paper n.4269, February.

Benàssy-Quéré A., Fontagné L. and A. Lahrèche-Révil, (2000), "Foreign Direct Investment and the Prospects for Tax Co-ordination in Europe", CEPII Document de travail n.06.

Blonigen B.A. and R.B. Davies, (2000), "The Effects of Bilateral Tax Treaties on US FDI Activity", NBER Working Paper, n.7929.

Brenton P., Di Mauro F. (1999), "The Potential Magnitude and Impact of FDI Flows to CEECs", Journal of Economic Integration, 14, 1, March.

Brenton P., Di Mauro F., Lucke M., (1999), "Economic Integration and FDI: an Empirical Analysis of Foreign Investment in the EU and in Central and Eastern Europe", Empirica, 26.

Deloitte and Touche, (1996), "European Investment Decision: The Impact of Tax Legislation on Investment in the European Union" (london: Deloitte and Touche)

Devereux M.P., Pearson M., (1995), "European Tax Harmonisation and Production Efficiency", European Economics Review, 39, 1655-1681.

Deveraux M.P., Freeman H., (1995) "The impact of Tax on Foreign Direct Investment: Empirical Evidence and the implication for Tax Integration Schemes", International Tax and Public Finance, vol.2, pp.85-106.

Deveraux M.P., Griffith R., (1998), Taxes and the Location of Production: Evidence from a Panel of US Multinationals", Journal of Public Economics, Vol.68, pp.335-367.

De Santis R. and C. Vicarelli (2001), “Fattori di attrazione degli investimenti diretti esteri nell'Unione Europea: il ruolo del contesto istituzionale e la competitività dell'Italia", Rivista di Politica Economica, $\mathrm{n}$.

Di Mauro F. (1999), "The Effects of Economic Integration on FDI Flows: an Empirical Analysis and a Comparison with Trade", CEPS Working Document, n.135, November.

Dunning J. H., (1977), "Trade, Location of Economic Activity and MNE: A Search for an Eclectic Approach" in Olhin B., Hesselborn P. and P. Wijkman (eds.), International Allocation of Economic Actvity, London, Macmillan.

Dunning J. H., (1981), International Production and Multinational Enterprise, London, George Allen \& Unwin. 
Eaton J., Tamura A. (1996), "Japanese and US exports and Investment as Conduit of Growth", NBER working paper, n.5457, February.

Fedeli F. and F. Forte (1999), "Concorrenza versus armonizzazione fiscale: la scelta delle regole del gioco nell'Unione Europea", in Bordignon M. e D. Da Empoli (a cura di), Concorrenza fiscale in un'economia internazionale integrata, Milano, Franco Angeli. pp. 78-103.

Gorter J. and A. Parikh (2000), "How mobile is capital within the European Union", Centraal Planbureau Working Paper n.172, The Hague, November.

Giannini S. (2001), "La tassazione del reddito d'impresa e le scelte di investimento, finanziamento e localizzazione dell'attività produttiva", Materiali di Discussione, Dipartimento di Economia Politica, Università di Modena e Reggio Emilia, n. 352.

Gropp R. and K. Kostial (2000), "The Disappearing Tax Base: Is Foreign Direct Investment Eroding Corporate Income Taxes?”, IMF Working Paper n.173.

Hartmann D., (1984), “Tax Policy and Foreign Direct Investment in the United Staes”, National Tax Journal, vol.37, pp.475-487.

Helpman E. (1984), “A Simply Theory of International Trade with Multinational Corporations”, Journal of Political Economy, 92, 31.

Helpman E., Krugman P. (1985), Market Structure and Foreign Trade, Cambridge Mass., MIT Press.

Hines J.R.(1996), “Tax Policy and the Activities of Multinational Corporations”, NBER Working Paper, n.5589.

Layard R., Nickell S .and R. Jackman (1991), Unemployment, Macroeconomic Performance and Labour Market, New York, OUP.

Linnemann H., (1966), “An Econometric Study of International Trade Flows”, North-Holland, Amsterdam.

Martinez-Mongay C., (2000), "ECFIN's Effective tax rates. Properties and Comparisons with other tax indicators.", Economic Papers European Commission n.146, October.

Markusen J.R, (1995), "The boundaries of Multinational Enterprise and the Theory of Intrenational Trade", Journal of Economic Perpective, vol.9, n.2, pp169-189.

Markusen J.R., Maskus K.E., (1999a), "Discriminating among Alternative Theories of the Multinational Enterprise", NBER Working Paper No.7164, Washington D.C.

Markusen J.R., Maskus K.E., (1999b), "Multinational Firms: Reconciling Theory and Evidence”, NBER Working paper No.7163, Washington D.C.

Markusen J.R., Venables A.J., Konan D.E. and K.H. Zhang (1996), “A Unified Treatment of Horizontal Direct Investment, Vertical Direct Investment, and the Pattern of Trade in Goods and Services", NBER Working Paper no.5696, Washington D.C.

Mori A. and V. Rolli (1998), “Investimenti diretti all'estero e commercio: complementi o sostituti?", Banca d'Italia Temi di Discussione n.337, October. 
Persson T., G. Tabellini (1992), “The Politics of 1992: Fiscal Policy and European Integration”, Review of Economic Studies, 59, 689-701.

Schlitzer G., Zaghini A., (2000), "Investimenti diretti esteri e regimi fiscali: un confronto tra paesi europei", Rivista di Politica Economica, gennaio.

UN (1992), The Determinants of Foreign Direct Investment: a Survey of the Evidence, New York, UN Centre on Transnational Corporations.

UNCTAD (1998), World Investment Report: Trends and Determinants, Geneva.

UNCTAD (2000), World Investment Report", Ginevra.

Yamada T. and T. Yamada (1996), "Integration and Japanese FDI in EC", Contemporary Economic Policy, n.14, pag.47-57.

Young K., (1988), "The Effects of Taxes and Rates of Return on Foreign Direct Investment in the United Staes", National Tax Journal vol.41, pp.109-121. 